\title{
Review
}

\section{Platinum drugs in the treatment of non-small-cell lung cancer}

\author{
J Cosaert' and E Quoix*,2 \\ 'AstraZeneca, Mereside, Alderley Park, Macclesfield, Cheshire, SKIO 4TG, UK; ${ }^{2}$ Senvice de Pneumologie Lyautey, Hôpitaux Universitaires, I, Place de l'Hôpital, \\ 67091 Strasbourg, France
}

\begin{abstract}
The use of chemotherapy is considered standard therapy in patients with locally advanced non-small-cell lung cancer that cannot be treated with radiotherapy and in those with metastatic non-small-cell lung cancer and good performance status. This approach is also accepted in patients with earlier stage disease, when combined with radiotherapy in those with nonresectable locally advanced disease, or in the preoperative setting. Randomised clinical studies and meta-analyses of the literature have confirmed the beneficial survival effect of platinum-based chemotherapy. Cisplatin and carboplatin have been successfully used with other drugs in a wide variety of well-established two-drug combinations while three-drug combinations are still under investigation. Cisplatin and carboplatin use is limited by toxicity and inherent resistance. These considerations have prompted research into new platinum agents, such as the trinuclear platinum agent BBR3464, the platinum complex ZD0473 and oxaliplatin. These compounds could be developed in combination with agents such as paclitaxel, gemcitabine or vinorelbine in patients with advanced and/or refractory solid tumours.

British Journal of Cancer (2002) 87, 825 -833. doi: I 0.1038/sj.bjc.6600540 www.bjcancer.com

(c) 2002 Cancer Research UK
\end{abstract}

Keywords: cisplatin; carboplatin; ZD0473; BBR3464; oxaliplatin; non-small-cell lung cancer

Lung cancer has the highest mortality rate of any major malignancy in the developed world, causing an estimated 1 million deaths worldwide annually (Abratt, 1995). In the United States alone it has been estimated that 157400 deaths from lung cancer will occur in 2001 (American Cancer Society (http://www.cancer. org/ (accessed 18 September 2001)). Mortality due to lung cancer exceeds that related to breast, prostate, colorectal and ovarian cancers combined (American Cancer Society, 2001). Approximately $85-90 \%$ of cases of lung cancer are attributable to smoking (Bunn et al, 1998).

Non-small-cell lung cancer (NSCLC) represents approximately $75-80 \%$ of all lung cancer (Abratt, 1995; Bunn et al, 1998; Natale, 1998). Fewer than $25 \%$ of patients have resectable disease, due to locally advanced or metastatic disease, which does not allow surgery despite improvements in diagnosis and peri- and postoperative care (Bulzebruck et al, 1992). Also, comorbidities, mostly linked to tobacco, may prevent patients with potentially resectable disease from receiving surgery. Overall 5-year survival is between 5 and $13 \%$, and varies with the different stages of the disease (Johnson, 1995; Mountain, 1997; Natale, 1998; Breathnach et al, 2001).

This review outlines current treatment options for patients with NSCLC with emphasis on the use of platinum-containing regimens. This disease is inherently resistant to chemotherapy and is associated with lower response rates than many other malignancies (Bunn et al, 1998; Natale, 1998) and the optimal treatment is yet to be determined (Breathnach et al, 2001).

\section{MANAGEMENT OF NSCLC}

Surgery or radiotherapy is the standard option for patients with early stages of NSCLC. Chemotherapy has shown benefit when

*Correspondence: E Quoix; E-mail: elisabeth.quoix@chru-strasbourg.fr Received 8 February 2002; revised 4 July 2002; accepted 23 July 2002 used alone in patients with stage IV disease, in combination with radiotherapy in patients with locally advanced disease and in the preoperative setting in those with early stages of NSCLC.

\section{Surgery and primary radiotherapy}

Surgery provides the best chance for cure of localised disease. It is therefore the treatment of choice in stages 0, I and II NSCLC (Deslauriers and Gregoire, 2000). With very careful patient selection, surgery may also be used as part of combined modality treatment in stages IIIA and IIIB (T4) disease (Rosell et al, 1994; Roth et al, 1994; CancerLinksUSA, http://www.cancer101.net (accessed May 26, 2001)) or stage IV disease to remove single metastatic lesions. However, even if surgery is the best treatment possible, the results are still unsatisfactory with a 5-year survival of less than $35 \%$. These results have led clinicians to evaluate combined modalities of treatment including chemotherapy.

Primary radiotherapy (with curative intent) can be considered in patients with inoperable stages I or II of the disease and sufficient pulmonary reserve. Analysis of one randomised and 26 nonrandomised studies in more than 2000 patients receiving radical radiotherapy for stage I or II disease found that 5-year survival rates ranged from 0 to $42 \%$ (Rowell and Williams, 2001). Primary radiotherapy used to be the 'gold standard' treatment in locally advanced NSCLC.

\section{Chemotherapy}

The poor efficacy and considerable toxicity of chemotherapy caused great pessimism for many years regarding this approach, as only a small impact on survival was observed.

During the 1980s, cisplatin and carboplatin were studied extensively in NCSLC (Bunn, 1989a,b). Randomised trials as well as meta-analyses provided scientific evidence that platinum-based therapy prolonged survival of patients with advanced NSCLC 
(stage IIIB with pleural effusions and stage IV) and advanced regional NSCLC (non resectable stages IIIA and IIIB disease) (NonSmall Cell Lung Cancer Collaborative Group, 1995). Experience over the past two decades has shown improvements in survival, symptom control and quality of life in patients with NSCLC who receive chemotherapy instead of best supportive care, and chemotherapy is now considered standard treatment in individuals with advanced NSCLC (Splinter, 1990; Non-Small Cell Lung Cancer Collaborative Group, 1995; Bunn and Kelly, 1998; Johnson, 2000; Bahl and Falk, 2001). More recently, platinum-based chemotherapy has shown to be of interest in the neoadjuvant setting, before surgery in patients with resectable stage IIIA (Rosell et al, 1994; Roth et al, 1998) and stages I to II disease (Depierre et al, 2002). Combined therapy with a platinum and taxane before surgery has also shown notable results, with a 1-year survival rate of $85 \%$ in patients with stages I to IIIa NCSLC reported after treatment with paclitaxel and carboplatin (Pisters et al, 2000). Another large randomised Intergroup trial is ongoing in the United States that is evaluating the efficacy of paclitaxel plus carboplatin in patients with early stage NSCLC.

The first generation agents in NSCLC (cisplatin, mitomycin-C, iphosphamide/cyclophosphamide, vindesine, vinblastine and etoposide) produced response rates ranging from 15 to $25 \%$ when used as monotherapy (Bakowski and Crouch, 1983; Grant and Kris, 1995) but, with the exception of cisplatin, had an unclear effect on survival. Second generation agents (gemcitabine, paclitaxel, docetaxel, vinorelbine, irinotecan and topotecan) showed response rates of 20-25\% (Bunn et al, 1998). Moreover, randomised studies comparing monochemotherapy with paclitaxel, gemcitabine or docetaxel versus best supportive care showed a survival benefit in the chemotherapy arm, (Anderson et al, 2000; Ranson et al, 2000; Roszkowski et al, 2000) emphasising the results of the meta-analysis of the NSCLCCOG (Non-Small Cell Lung Cancer Collaborative Group, 1995). Additional reports of large randomised trials (one a pooled analysis of two trials), each conducted in more than 700 patients, have confirmed the survival benefit of cisplatinbased combined two- or three-agent chemotherapy versus best supportive care (Cullen et al, 1999; Stephens et al, 2002).

\section{Cisplatin and carboplatin}

Platinum agents have currently shown the greatest promise in patients with NSCLC. These agents induce their cytotoxic effects by targeting cellular DNA and are active against a number of tumour types (Go and Adjei, 1999). Cisplatin is thought to act by activating apoptosis and altering a number of other cellular parameters. It forms adducts with all DNA bases but preferentially binds to the $N^{7}$ positions of guanine and adenine in intact DNA. The main DNA lesions produced by both cisplatin and carboplatin, accounting for a total of $95 \%$ of platinum-DNA adducts, are at the G-G, A-G and G-X-G intrastrand crosslinks (Fink and Howell, 2000).

The dosages at which these agents are given varies according to the agent(s) with which they are being combined and the status of the patient. However, cisplatin is usually given at a dosage of $50-$ $120 \mathrm{mg} \mathrm{m}^{-2}$ per cycle, whereas the dose of carboplatin is usually customised for each patient using the area under the concentration-time curve (AUC) and renal function of the patient (Calvert et al, 1989; Chatelut et al, 1995), because this drug undergoes extensive renal excretion. An AUC of 4-6 per cycle, which is approximately equivalent to a dose in the range 200$350 \mathrm{mg} \mathrm{m}^{-2}$ per cycle, is usual. Both platinum agents are usually given every 3-4 weeks, according to the haematological status of the patient, for 3-6 cycles.

Analysis of the Southwest Oncology Group (SWOG) database of 2531 patients with extensive NSCLC (1974-1988) showed the use of cisplatin to be an independent predictor of improved outcome
(Albain et al, 1991). Thus, most clinical studies of chemotherapy in advanced or locoregionally advanced NSCLC in recent years have incorporated cisplatin. However, because of the toxicity of cisplatin (see below), less toxic platinum alternatives have been developed. The most extensively evaluated has been carboplatin (Bunn, 1989b), with studies demonstrating the efficacy of carboplatin, alone (Bonomi et al, 1989; Bunn, 1989a,b; Gatzemeier et al, 1990a; Kreisman et al, 1990) or in combination (Gatzemeier et al, 1990b). The available data suggest that carboplatin can substitute cisplatin in patients with stage IIIB/IV NSCLC (Lokich and Anderson, 1998; Go and Adjei, 1999; Zatloukal et al, 2001). However, direct comparisons between cisplatin- and carboplatinbased chemotherapy have been very rare (Klastersky et al, 1990; Gatzemeier et al, 1999). Rodriguez et al (2001) presented the results of a randomised study comparing docetaxel plus cisplatin or carboplatin versus vinorelbine plus cisplatin at the 2001 meeting of the American Society of Clinical Oncology. Although the study was not designed to compare carboplatin with cisplatin, results in the carboplatin arm were inferior.

Two drug combinations Two types of trials have been conducted to compare monochemotherapy with cisplatin-containing two agent chemotherapy: comparisons with cisplatin monotherapy and comparisons using monotherapy with the non-platinum agent. The relative benefits of combination therapy over monotherapy, shown in many publications, resulted in combination therapy becoming recognised standard practice (Splinter, 1990; Marino et al, 1995; Lilenbaum et al, 1998) and a number of phase III studies are currently underway or completed that investigate the relative efficacies of several new platinum-containing two-agent combination regimens (Table 1) (Kelly et al, 2001; Rodriguez et al, 2001; Scagliotti et al, 2001; van Meerbeeck et al, 2001; Schiller et al, 2002).

Of note, Schiller et al (2002) compared cisplatin plus paclitaxel (the ECOG standard of care) with the new combination regimens of cisplatin plus gemcitabine or docetaxel and paclitaxel plus carboplatin (four-arm study). No major differences were observed in terms of efficacy (objective response rate and survival) or toxicity. Similar findings were reported in a trial comparing paclitaxel plus carboplatin with vinorelbine plus cisplatin (Kelly et al, 2001).

Comparisons between cisplatin containing double therapy and monotherapy with the non-platinum agent Results of trials comparing monotherapy with vindesine (Elliott et al, 1984; Einhorn et al, 1986), etoposide (Rosso et al, 1990), teniposide (Splinter et al, 1996), and vinorelbine (Depierre et al, 1994; Le Chevalier et al, 1994) with the respective agent combined with cisplatin showed consistently higher response rates in the combination therapy arm, but only about half showed a survival benefit for the combination (Table 2). Similarly, preliminary analysis of a multicenter phase III trial comparing docetaxel $v s$ docetaxel plus cisplatin in patients with inoperable advanced and metastatic NSCLC showed no survival advantage but a significant improvement in objective response rate with combination therapy (Georgoulias et al, 2002; Table 2).

Comparisons between cisplatin containing double therapy and cisplatin monotherapy Comparisons of cisplatin monotherapy and combination therapy with cisplatin plus vindesine (Kawahara et al, 1991), etoposide (Klastersky et al, 1989; Crino et al, 1990), vinorelbine (Wozniak et al, 1998), paclitaxel (Gatzemeier et al, 2000), gemcitabine (Sandler et al, 2000) and tirapazamine (von Pawel et al, 2000) consistently showed a higher response rate in the combination therapy arm, but again only half of the trials showed a survival benefit for the combination therapy arm (Table 3).

Comparisons between carboplatin containing double therapy and monotherapy with the non-platinum agent A comparison between monotherapy with paclitaxel and paclitaxel plus carbopla- 
Table I Recent phase III studies comparing platinum-based two agent combination therapies for patients with stage IIIb or IV NSCLC

\begin{tabular}{|c|c|c|c|}
\hline Trial & Platinum & Additional agent & Frequency \\
\hline Kelly et al (200I) & $\begin{array}{l}\text { Cisplatin } 100 \mathrm{mg} \mathrm{m}^{-2} \mathrm{~d} 2 \\
\text { Carboplatin AUC } 6 \mathrm{dl}\end{array}$ & $\begin{array}{l}\text { Vinorelbine } 25 \mathrm{mg} \mathrm{m}^{-2} \text { week }^{-1} \\
\text { Paclitaxel } 225 \mathrm{mg} \mathrm{m}^{-2} \mathrm{dl}\end{array}$ & $\begin{array}{l}\text { Every } 28 \text { days } \\
\text { Every } 21 \text { days }\end{array}$ \\
\hline Rodriguez et al (200I) & $\begin{array}{l}\text { Cisplatin } 75 \mathrm{mg} \mathrm{m}^{-2} \mathrm{dl} \\
\text { Carboplatin } \mathrm{A \cup C} 6 \mathrm{dl} \\
\text { Cisplatin } 100 \mathrm{mg} \mathrm{m}^{-2} \mathrm{dl}\end{array}$ & $\begin{array}{l}\text { Docetaxel } 75 \mathrm{mg} \mathrm{m}^{-2} \mathrm{dl} \\
\text { Docetaxel } 75 \mathrm{mg} \mathrm{m}^{-2} \mathrm{dl} \\
\text { Vinorelbine } 25 \mathrm{mg} \mathrm{m}^{-2} \mathrm{dl}, \mathrm{d} 7, \mathrm{dl} 4, \mathrm{~d} 2 \mathrm{l}\end{array}$ & $\begin{array}{l}\text { Every } 21 \text { days } \\
\text { Every } 21 \text { days } \\
\text { Every } 28 \text { days }\end{array}$ \\
\hline Scagliotti et al (200I) & $\begin{array}{l}\text { Cisplatin } 75 \mathrm{mg} \mathrm{m}^{-2} \mathrm{~d} 2 \\
\text { Carboplatin } \mathrm{A \cup C} 6 \mathrm{dl} \\
\text { Cisplatin } 100 \mathrm{mg} \mathrm{m}^{-2} \mathrm{dl}\end{array}$ & $\begin{array}{l}\text { Gemcitabine } 1250 \mathrm{mg} \mathrm{m}^{-2} \mathrm{dl}, \mathrm{d} 8 \\
\text { Paclitaxel } 225 \mathrm{mg} \mathrm{m}^{-2} \mathrm{dl} \\
\text { Vinorelbine } 25 \mathrm{mg} \mathrm{m}^{-2} \mathrm{dl}, \mathrm{d} 7, \mathrm{dl} 4, \mathrm{~d} 2 \mathrm{I} \times 2 \text { then } \mathrm{dl}, \mathrm{dl} 4\end{array}$ & $\begin{array}{l}\text { Every } 21 \text { days } \\
\text { Every } 21 \text { days } \\
\text { Every } 28 \text { days }\end{array}$ \\
\hline Van Meerbeeck et al (200I) & $\begin{array}{l}\text { Cisplatin } 80 \mathrm{mg} \mathrm{m}^{-2} \mathrm{dl}^{-2} \\
\text { Cisplatin } 80 \mathrm{mg} \mathrm{m}^{-2} \mathrm{dl}\end{array}$ & $\begin{array}{l}\text { Paclitaxel } 175 \mathrm{mg} \mathrm{m}^{-2} \mathrm{dl} \\
\text { Gemcitabine } 1250 \mathrm{mg} \mathrm{m}^{-2} \mathrm{dl}, \mathrm{d} 8 \\
\text { Paclitaxel } 175 \mathrm{mg} \mathrm{m}^{-2} \mathrm{dl}+\text { gemcitabine } 1250 \mathrm{mg} \mathrm{m}^{-2} \mathrm{dl}, \mathrm{d} 8\end{array}$ & $\begin{array}{l}\text { Every } 21 \text { days } \\
\text { Every } 21 \text { days } \\
\text { Every } 21 \text { days }\end{array}$ \\
\hline
\end{tabular}

Table 2 Comparisons between cisplatin containing double therapy and monotherapy with the second agent in patients with advanced NSCLC

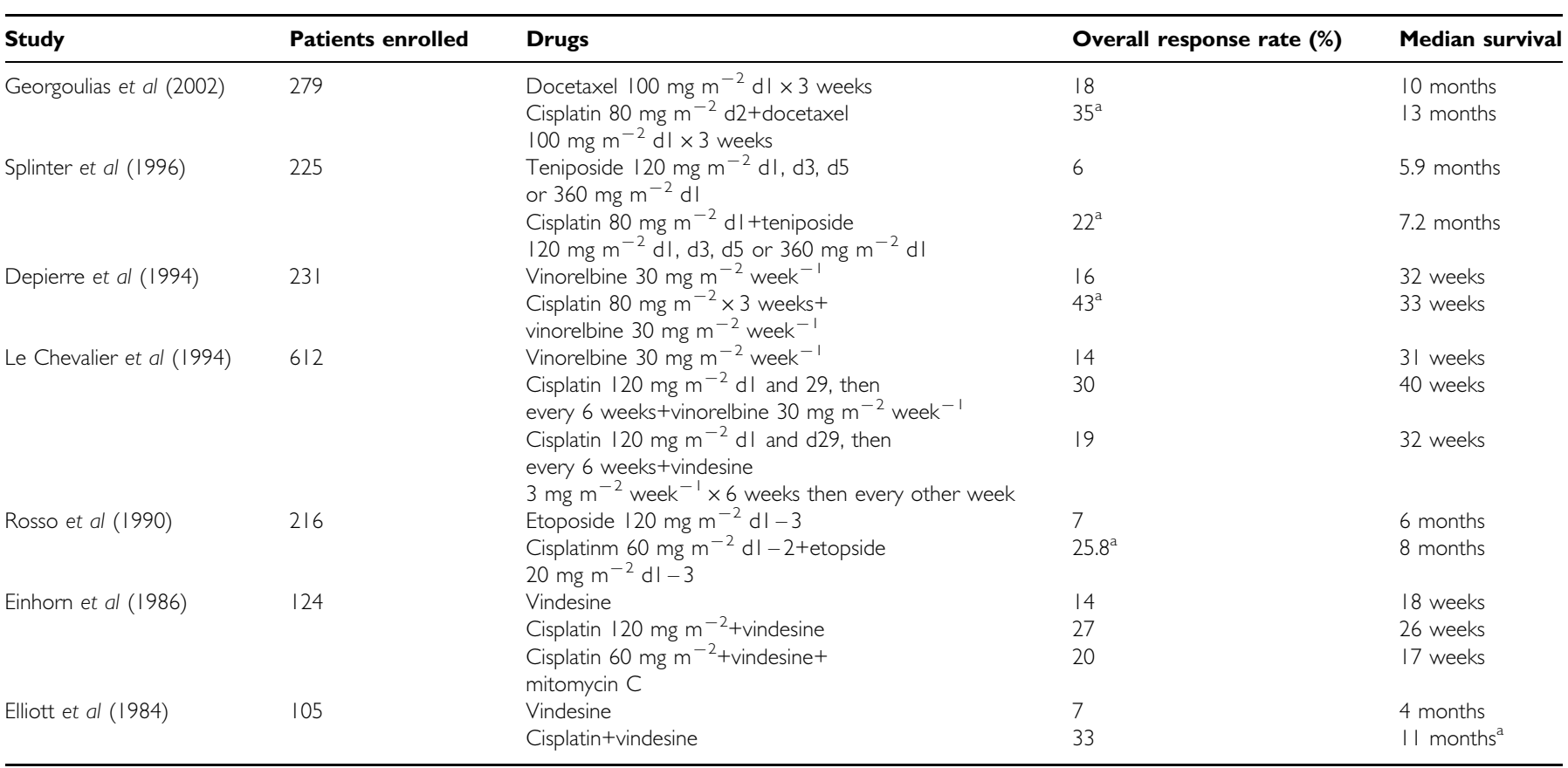

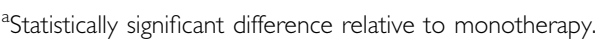

tin in 584 patients with advanced NSCLC showed a significant advantage in terms of objective response rate (16 vs $30 \%$, $P<0.0001)$ and survival distribution $(6.5$ vs 8.5 months, $P=0.023)$ in favour of combination therapy but no significant difference between treatments in 1-year survival rate (31 vs 36\%) (Lilenbaum et al, 2002). Similarly, a comparison of gemcitabine with gemcitabine plus carboplatin in 275 patients with advanced NSCLC showed higher objective response rates (12 vs 30\%) and a significantly longer time to progression (4 vs 6 months, $P=0.001$ ) with combination therapy; the median survival was 9 months for the whole study population (Sederholm, 2002).

Conclusions The survival results reported to date suggest that the importance of inclusion of a platinum agent in the combination therapy setting is still at least open for discussion, although it appears to be accepted that two-agent combination therapy is better than monotherapy.
Three drug combinations No statistically significant survival difference has been observed between regimens containing cisplatin in combination with doxorubicin and cyclophosphamide (CAP), doxorubicin and 5-fluorouracil (AFP), cyclophosphamide and bleomycin (CBP), vindesine (VP), etoposide (EP), or vindesine and mitomycin-C (MVP). Median survival ranged from 21.6 to 26.6 weeks. The MVP regimen showed a trend towards a higher response rate than the other regimens in certain trials with no benefit on survival (Ruckdeschel et al, 1985). MVP showed superiority to EP in another trial (Ginopoulos et al, 1997). A recent trial that compared triple therapy with cisplatin plus ifosfamide plus mitomycin (MIP) with gemcitabine plus cisplatin showed a higher response rate in the 'modern' double therapy regimen and no difference in survival between the two arms (Crino et al, 1999). Other comparisons between double and triple therapy with modern drugs did not show any advantage for triple therapy over double therapy (Alberola et al, 2001; Souquet et al, 2001). 
Table 3 Comparisons between cisplatin containing double therapy and cisplatin monotherapy in patients with advanced NSCLC

\begin{tabular}{|c|c|c|c|c|}
\hline Study & Patients enrolled & Drugs & Overall response rate (\%) & Median survival \\
\hline Gatzemeier et al (2000) & 414 & $\begin{array}{l}\text { Cisplatin } 100 \mathrm{mg} \mathrm{m}^{-2} \times 3 \text { weeks } \\
\text { Cisplatin } 80 \mathrm{mg} \mathrm{m}^{-2} \times 3 \text { weeks } \\
\text { paclitaxel } 175 \mathrm{mg} \mathrm{m}^{-2} \times 3 \text { weeks }\end{array}$ & $\begin{array}{l}17 \\
26^{\mathrm{a}}\end{array}$ & $\begin{array}{l}8.6 \text { months } \\
8.1 \text { months }\end{array}$ \\
\hline von Pawel et al (2000) & 437 & $\begin{array}{l}\text { Cisplatin } 75 \mathrm{mg} \mathrm{m}^{-2} \times 3 \text { weeks } \\
\text { Cisplatin } 75 \mathrm{mg} \mathrm{m}^{-2} \times \text { +tirapazamine } \\
390 \mathrm{mg} \mathrm{m}^{-2} \times 3 \text { weeks }\end{array}$ & $\begin{array}{l}14 \\
28^{\mathrm{a}}\end{array}$ & $\begin{array}{l}27.7 \text { weeks } \\
34.6 \text { weeks }^{a}\end{array}$ \\
\hline Kawahara et al (199|) & 160 & $\begin{array}{l}\text { Cisplatin } 80 \mathrm{mg} \mathrm{m}^{-2} \mathrm{dl} \\
\text { Cisplatin } 80 \mathrm{mg} \mathrm{m}^{-2} \mathrm{dl}+\text { +vindesine } \\
3 \mathrm{mg} \mathrm{m}^{-2} \mathrm{dl}, \mathrm{d} 8, \mathrm{dl} 5\end{array}$ & $\begin{array}{l}12 \\
29^{a}\end{array}$ & $\begin{array}{l}39 \text { months } \\
45 \text { weeks }\end{array}$ \\
\hline Crino et al (1990) & 156 & $\begin{array}{l}\text { Cisplatin } 120 \mathrm{mg} \mathrm{m}^{-2} \times 3 \text { weeks } \\
\text { Cisplatin } 120 \mathrm{mg} \mathrm{m}^{-2}+\text { etoposide } \\
100 \mathrm{mg} \mathrm{m}^{-2} \mathrm{dl}-3 \times 3 \text { weeks } \text { Cisplatin } 120 \mathrm{mg} \mathrm{m}^{-2}+\text { etopside } \\
100 \mathrm{mg} \mathrm{m}^{-2} \mathrm{dl}^{-3} \times 3 \text { weeks+ } \\
\text { mitomycin-C } 10 \mathrm{mg} \mathrm{m}^{-2} \mathrm{dl}, \mathrm{d} 2 \mathrm{I}, \mathrm{d} 42 \text {, then 6-weekly }\end{array}$ & $\begin{array}{l}4 \\
30 \\
26\end{array}$ & $\begin{array}{l}18 \text { weeks } \\
35 \text { weeks }^{\mathrm{a}} \\
37 \text { weeks }^{\mathrm{a}}\end{array}$ \\
\hline Klastersky et al (1989) & 162 & $\begin{array}{l}\text { Cisplatin } 120 \mathrm{mg} \mathrm{m}^{-2} \mathrm{dl} \\
\text { Cisplatin } 120 \mathrm{mg} \mathrm{m}^{-2} \mathrm{dl}+\text { etoposide } \\
100 \mathrm{mg} \mathrm{m}^{-2} \mathrm{dl}^{-3}\end{array}$ & $\begin{array}{l}19 \\
26\end{array}$ & $\begin{array}{l}26 \text { weeks } \\
22 \text { weeks }\end{array}$ \\
\hline
\end{tabular}

${ }^{a}$ Statistically significant difference relative to monotherapy.

\section{Regimens containing oxaliplatin}

Three small studies are underway to assess combinations of oxaliplatin and gemcitabine (Franciosi et al, 2001), paclitaxel (Hoffman et al, 2001) or vinorelbine (Monnet et al, 2002) in patients with advanced NSCLC. Early results in 24 previously untreated (Hoffman et al, 2001), 28 previously untreated (Monnet et al, 2002) and 10 previously treated (Franciosi et al, 2001) patients show response rates of 25,35 and $30 \%$, respectively. Oxaliplatin monotherapy has also demonstrated activity in a small study of 33 patients with poor-prognosis NSCLC (Monnet et al, 1998).

\section{Other chemotherapy options}

In addition, combinations of paclitaxel or docetaxel with nonplatinum agents such as gemcitabine have shown promising results (Douillard et al, 2001b; Georgoulias et al, 2001). Indeed, such combinations may be an option for patients unable to tolerate platinum agents or those with compromised performance status. In addition, patients with a performance status of 2 do not benefit from platinum-based chemotherapy (Soria et al, 2001). In general, studies comparing non-platinum regimens with platinum-based regimens are still ongoing. In one that is published (Georgoulias et al, 2001), no significant difference was seen between gemcitabine plus docetaxel and cisplatin plus docetaxel. The results of such trials need to be confirmed.

Several of the newer agents have been studied as second line chemotherapy in patients with NSCLC and have shown some efficacy (Socinski and Langer, 1999; Huisman et al, 2000; Miller and Kris, 2000), especially docetaxel for which there has been two randomised studies (Fossella, 1999a,b; Shepherd et al, 2000).

\section{Combined modality and adjuvant therapy}

The use of platinum-based chemotherapy in conjunction with radiotherapy in patients with locally advanced unresectable NSCLC has become standard since the studies of Le Chevalier et al (1991) and Dillman et al (1990). The NSCLCCG meta-analy- sis confirmed the survival benefit provided by giving cisplatinbased chemotherapy before radiotherapy over radiotherapy alone (Non-Small Cell Lung Cancer Collaborative Group, 1995). Although it is standard to use induction chemotherapy followed by radiotherapy, there are some arguments favouring concurrent chemoradiation using chemotherapy at systemic dosages (Eberhardt et al, 1998; Jeremic et al, 1999) or at radiosensitising dosages (Trovo et al, 1992; Schaake-Koning et al, 1994; Bardet et al, 1997; Clamon et al, 1999). These two different treatment modalities have been studied in a number of promising phase II trials but there are very limited data from positive randomised phase III trials (Schaake-Koning et al, 1994; Furuse et al, 1999). Results of these phase III studies support the use of concurrent chemotherapy and radiotherapy in preference to radiotherapy alone (Schaake-Koning et al, 1994) or sequential chemotherapy then radiotherapy (Furuse et al, 1999).

\section{Problems with currently used platinum drugs}

Toxicity Severe adverse effects limit the use of cisplatin (McKeage, 1995). Nephrotoxicity may be reduced but not suppressed by hyper-hydration (Hamilton et al, 1989; Bissett et al, 1990). However, this hyper-hydration is not possible in patients with congestive heart failure, a condition that is not rare in patients with NSCLC. Cisplatin is also one of the most emetogenic drugs used, with considerable variability between individuals. Systematic use of serotonin antagonists has improved control of acute emesis but not delayed emesis (Fauser et al, 1999; Gralla et al, 1999). Anemia can also occur during treatment with cisplatin. This can be due to several mechanisms, including depletion of intrinsic erythropoietin production (caused by peritubular renal cell depletion), reduced bone marrow stem cell activity and the absence of the stem cell reaction of administered erythropoietin (Dufour et al, 1990; Canpolat et al, 1994; Wood and Hrushesky, 1995).

Nephrotoxicity and neurotoxicity have been considerably reduced by replacing cisplatin with carboplatin, which shows nephrotoxicity only when used in high dosages. Carboplatin, however, causes dose-limiting myelosuppression (McKeage, 1995; 
Bunn, 1989b; ; Judson and Kelland, 2000). Transient rises in bilirubin levels have also been observed (Fields et al, 1995).

Resistance Kelland (2000) and Giaccone (2000) reviewed recently in detail the inherent resistance of NSCLC to current platinums. NCSLC is inherently resistant to treatment with cisplatin (Giaccone, 2000), so an understanding of the mechanisms behind this could help to improve the prognosis of many patients with the cancer. Thus, resistance to cisplatin has been studied extensively in vitro. A number of resistance mechanisms have been identified including: (a) increased repair of platinum-induced DNA damage (increased nucleotide excision repair or loss of DNA mismatch repair); (b) glutathione or metallothionein drug deactivation; (c) reduced cellular uptake of the platinum; (d) altered apoptosis (Kelland, 2000).

The clinical relevance of these mechanisms is currently not entirely clear; however, tumour cell overexpression of metallothionein has been shown to correlate with chemo-resistance and prognosis in patients with oesophageal and urothelial cancer (Go and Adjei, 1999). Similarly, clinical trials have shown that prognosis is related to lung resistance-related protein abnormalities, which may alter transport of cisplatin; increased repair of cisplatin-DNA adducts; and loss of mismatch repair (Fink and Howell, 2000; Giaccone, 2000). Nucleotide excision repair appears to be the most important pathway for cisplatin-DNA damage, and the critical gene appears to be excision repair cross-complementing (ERCC1) (Giaccone, 2000). A number of studies have shown that high levels of the ERCC1 relative messenger RNA are associated with response and survival after cisplatin treatment (Giaccone, 2000; Rosell and Felip, 2001). Another genetic abnormality though to be related to cisplatin resistance affects the apoptosis gene p53; $60 \%$ of NSCLC patients have p53 mutations (Giaccone, 2000). Resistance to carboplatin is less well studied, but it is assumed that similar mechanisms are involved (Go and Adjei, 1999). The pharmacogenomics of these agents is therefore being intensively studied and may dictate therapy choices in the future.

\section{New platinum agents}

The problems associated with the use of current platinum agents, and the need to improve response and survival in patients with NSCLC (and other cancers), have prompted research into new platinum agents that have improved toxicity profiles, may circumvent resistance mechanisms, and have administration schedules that are acceptable to physicians and patients.

New agents include nedaplatin, a cisplatin-like compound registered in Japan and active in NSCLC (Judson et al, 1997), and satraplatin, an orally available drug with dose-limiting toxicity similar to that of carboplatin currently being explored in prostate cancer. Two other novel agents, BBR3464 and ZD0473, have shown good results in preclinical and in vitro studies, and have potential in the treatment of solid tumours (Judson and Kelland, 2000).

BBR3464 BBR3464 is a trinuclear platinum complex that binds to DNA more rapidly than cisplatin and forms long-range interstrand and intrastrand crosslinks. Phase I studies show diarrhoea and neutropenia to be dose-limiting toxicities, without significant nephro-, neuro- or pulmonary toxicity (Calvert et al, 1999; Sessa et al, 2000). Antitumour activity was observed in colorectal and pancreatic cancer patients after a one-hour infusion of $1.1 \mathrm{mg} \mathrm{m}^{-2}$ every 28 days (Calvert et al, 1999). A second study (Sessa et al, 2000) showed similar toxicity $\left(0.03-0.17 \mathrm{mg} \mathrm{m}^{-2}\right.$ day $^{-1}$ for 5 days, repeated every 28 days), in patients with solid tumours unresponsive to previous antitumour treatment. Phase II trials are currently underway.

ZD0473 ZD0473 is a new-generation platinum agent designed to deliver an extended spectrum of antitumour activity and overcome platinum resistance mechanisms. A common mechanism of resistance is the replacement of the platinum centre by a thiol moiety. This substitution is hindered by increasing the steric bulk of the molecule, and ZD0473, with its methyl-substituted pyridine side chain, was designed with this property in mind (Holford et al, 1998b).

Biochemical studies show that ZD0473 at least partially overcomes mechanisms of inherent or acquired resistance (Holford et al, 1998a), and preclinical work indicates activity against cell lines resistant to older platinum agents (Raynaud et al, 1997). In man, dose-limiting toxicity is myelosuppression, particularly in patients previously treated with carboplatin (Trigo et al, 1999; Hoctin-Boes et al, 2001); without evidence of clinically relevant neurotoxicity, nephrotoxicity or ototoxicity when given at doses of 120 or $150 \mathrm{mg} \mathrm{m}^{-2}$ (Hoctin-Boes et al, 2001).

Of the newer platinum agents, the new-generation agent ZD0473 could be of interest in NSCLC, with good tolerability having been reported in phase I trials in which the drug has been given in combination with paclitaxel, gemcitabine or vinorelbine in patients with advanced and/or refractory solid tumours (Table 4). These trials are ongoing, as are phase II monotherapy studies of first- and second-line treatment in patients with NSCLC in which ZD0473 is being given at a dosage of $120-150 \mathrm{mg} \mathrm{m}^{-2}$ every 3 weeks.

\section{CONCLUSIONS}

Chemotherapy is now broadly accepted in stage IIIB/IV NSCLC, and there is growing interest in its use in earlier disease when

Table 4 Phase I studies of ZD0473 in combination with paclitaxel, gemcitabine or vinorelbine in patients with advanced solid tumours

\begin{tabular}{|c|c|c|c|}
\hline Study & Regimens & Patients & Results reported to date \\
\hline Douillard et al (200la) & $\begin{array}{l}\text { ZD0473 } 60-120 \mathrm{mg} \mathrm{m}^{-2} \mathrm{I}-2 \mathrm{~h} \\
\text { infusion } \mathrm{dl}+\text { vinorelbine } \\
15-30 \mathrm{mg} \mathrm{m}^{-2} 6-10 \mathrm{~min} \\
\text { infusion } \mathrm{dl} \text { and } 8 \text { every } 3 \text { weeks }\end{array}$ & $\begin{array}{l}\text { Patients with advanced solid } \\
\text { tumours }\end{array}$ & $\begin{array}{l}\text { No DLT reported for doses up to } \\
90 / 15 \mathrm{mg} \mathrm{m}^{-2} \text { ZD0473/vinorelbine }\end{array}$ \\
\hline Gatzemeier et al (200I) & $\begin{array}{l}\text { ZD047360, } 90 \text { or } \\
120 \mathrm{mg} \mathrm{m}^{-2} \mathrm{I} \mathrm{h} \text { infusion+ } \\
\text { paclitaxel } 135 \mathrm{mg} \mathrm{m}^{-2} 3 \mathrm{~h} \\
\text { infusion every } 3 \text { weeks }\end{array}$ & $\begin{array}{l}7 \text { NSCLC; } 2 \text { mesothelioma } \\
\text { I SCLC (all refractory } \\
\text { malignancies) }\end{array}$ & $\begin{array}{l}\text { Grade } 3-4 \text { leucopenia in four patients. No } \\
\text { DLT. SD in five out of seven evaluable patients } \\
\text { (including two NSCLC with } 25 \% \\
\text { reduction in tumour size) }\end{array}$ \\
\hline O'Dwyer et al (200I) & $\begin{array}{l}\text { ZD0473 } 60-120 \mathrm{mg} \mathrm{m}^{-2} \mathrm{I} \mathrm{h} \\
\text { infusion } \mathrm{dl}+\text { gemcitabine } \\
600-750 \mathrm{mg} \mathrm{m}^{-2} \mathrm{dl} \text { and } 8 \text { every } 3 \text { weeks }\end{array}$ & $\begin{array}{l}26 \text { with various advanced } \\
\text { solid tumours }\end{array}$ & $\begin{array}{l}\text { Grade } 3-4 \text { thrombocytopenia or grade } 4 \\
\text { neutropenia in seven patients. Two MR, both in } \\
\text { patients with gemcitabine- and cisplatin-pretreated } \\
\text { NSCLC; IO SD. No clinically } \\
\text { relevant nephro- or neurotoxicity }\end{array}$ \\
\hline
\end{tabular}


combined with other (local) therapy. Platinum drugs are still considered of crucial interest based on clinical studies and the results of meta-analyses, with the inconvenience of the observed toxicity and the inherent resistance. These observations have

\section{REFERENCES}

Abratt RP (1995) Current chemotherapy of advanced non-small cell lung cancer. Anticancer Drugs 6(Suppl 6): 15-18

Albain KS, Crowley JJ, LeBlanc M, Livingston RB (1991) Survival determinants in extensive-stage non-small-cell lung cancer: the Southwest Oncology Group experience. J Clin Oncol 9: 1618-1626

Alberola V, Camps C, Provencia M, Isla D, Rosell R, Vadell C, Bover I, RuizCasado A, Azagra P, Jimenez U, Ganzalez-Larriba JL, Cardenal F, Artal A, Carrato A, Morales S, Sanchez JJ (2001) Cisplatin/Gemcitabine (CG) vs. Cisplatin/Gemcitabine/Vinorelbine (CGV) vs. Sequential Doublets of Gemcitabine/Vinorelbine followed by Ifosfamide/Vinorelbine (GV/IV) in advanced Non-small cell lung cancer (NSCLC): Results of a Spanish Lung Cancer Group Phase III Trial (GEPC/98-02) (abstract). Proc Am Soc Clin Oncol 20: A1229

Anderson H, Hopwood P, Stephens RJ, Thatcher N, Cottier B, Nicholson M, Milroy R, Maughan TS, Falk SJ, Bond MG, Burt PA, Connolly CK, McIllmurray MB, Carmichael J (2000) Gemcitabine plus best supportive care (BSC) vs BSC in inoperable non-small cell lung cancer - a randomized trial with quality of life as the primary outcome. UK NSCLC Gemcitabine Group. Non-Small Cell Lung Cancer. Br J Cancer 83: 447-453

Bahl A, Falk S (2001) Meta-analysis of single agents in the chemotherapy of NSCLC: what do we want to know?. Br J Cancer 84: 1143-1145

Bakowski MT, Crouch JC (1983) Chemotherapy of non-small cell lung cancer: a reappraisal and a look to the future. Cancer Treat Rev 10: $159-172$

Bardet E, Riviere A, Charloux A, Spaeth D, Ducolone A, Le Groumellec A, Pellae-Cosset B, Henry-Amar M, Douillard JY (1997) A phase II trial of radiochemotherapy with daily carboplatin, after induction chemotherapy (carboplatin and etoposide), in locally advanced nonsmall-cell lung cancer: final analysis. Int J Radiat Oncol Biol Phys 38: 163-168

Bissett D, Kunkeler L, Zwanenburg L, Paul J, Gray C, Swan IR, Kerr DJ, Kaye SB (1990) Long-term sequelae of treatment for testicular germ cell tumours. Br J Cancer 62: 655-659

Bonomi PD, Finkelstein DM, Ruckdeschel JC, Blum RH, Green MD, Mason B, Hahn R, Tormey DC, Harris J, Comis R (1989) Combination chemotherapy versus single agents followed by combination chemotherapy in stage IV non-small-cell lung cancer: a study of the Eastern Cooperative Oncology Group. J Clin Oncol 7: 1602-1613

Breathnach OS, Freidlin B, Conley B, Green MR, Johnson DH, Gandara DR, O'Connell M, Shepherd FA, Johnson BE (2001) Twenty-two years of phase III trials for patients with advanced non-small-cell lung cancer: sobering results. J Clin Oncol 19: 1734-1742

Bulzebruck H, Bopp R, Drings P, Bauer E, Krysa S, Probst G, van Kaick G, Muller KM, Vogt-Moykopf I (1992) New aspects in the staging of lung cancer. Prospective validation of the International Union Against Cancer TNM classification. Cancer 70: $1102-1110$

Bunn Jr PA (1989a) The expanding role of cisplatin in the treatment of nonsmall-cell lung cancer. Semin Oncol 16: $10-21$

Bunn Jr PA (1989b) Review of therapeutic trials of carboplatin in lung cancer. Semin Oncol 16: $27-33$

Bunn Jr PA, Kelly K (1998) New chemotherapeutic agents prolong survival and improve quality of life in non-small cell lung cancer: a review of the literature and future directions. Clin Cancer Res 4: 1087-1100

Bunn Jr PA, Vokes EE, Langer CJ, Schiller JH (1998) An update on North American randomized studies in non-small cell lung cancer. Semin Onco 25: $2-10$

Calvert PM, Highley MS, Hughes AN, Plummer ER, Azzabi AST, Verrill MW Camboni MG, Verdie, Bernareggi A, Zuchetti M, Robinson AM, Carmichael J, Calvert AH (1999) A phase I study of a novel, trinuclear, platinum analogue, BBR3464, in patients with advanced solid tumors (abstract/poster no. 333). Clin Cancer Res 5: (Suppl): 3796

Calvert AH, Newell DR, Gumbrell LA, O’Reilly S, Burnell M, Boxall FE, Siddik ZH, Judson IR, Gore ME, Wiltshaw E (1989) Carboplatin dosage: prospective evaluation of a simple formula based on renal function. J Clin Oncol 7: $1748-1756$ prompted the development of second generation drugs and newer platinums (oxaliplatin, BBR3464, ZD0473) and any relative benefits for these approaches will be investigated in the ongoing trials.
Canpolat C, Pearson P, Jaffe N (1994) Cisplatin-associated hemolytic uremic syndrome. Cancer 74: 3059-3062

Chatelut E, Dezeuze A, Lavit M, Chevreau C, Pujol A, Boneu A, Roche H, Houin G, Bugat R, Canal P (1995) Prediction of carboplatin clearance from morphological and biological patient characteristics (In French). Bull Cancer 82: $946-953$

Clamon G, Herndon J, Cooper R, Chang AY, Rosenman J, Green MR (1999) Radiosensitization with carboplatin for patients with unresectable stage III non-small-cell lung cancer: a phase III trial of the Cancer and Leukemia Group B and the Eastern Cooperative Oncology Group. J Clin Oncol 17: $4-11$

Crino L, Scagliotti GV, Ricci S, De Marinis F, Rinaldi M, Gridelli C, Ceribelli A, Bianco R, Marangolo M, Di Costanzo F, Sassi M, Barni S, Ravaioli A, Adamo V, Portalone L, Cruciani G, Masotti A, Ferrara G, Gozzelino F, Tonato M (1999) Gemcitabine and cisplatin versus mitomycin, iphosphamide, and cisplatin in advanced non-small-cell lung cancer: A randomized phase III study of the Italian Lung Cancer Project. J Clin Oncol 17: 3522 3530

Crino L, Tonato M, Darwish S, Meacci ML, Corgna E, Di Costanzo F, Buzzi F, Fornari G, Santi E, Ballatori E (1990) A randomized trial of three cisplatin-containing regimens in advanced non-small-cell lung cancer (NSCLC): a study of the Umbrian Lung Cancer Group. Cancer Chemother Pharmacol 26: $52-56$

Cullen MH, Billingham LJ, Woodroffe CM, Chetiyawardana AD, Gower NH, Joshi R, Ferry DR, Rudd RM, Spiro SG, Cook JE, Trask C, Bessell E, Connolly CK, Tobias J, Souhami RL (1999) Mitomycin, ifosfamide, and cisplatin in unresectable non-small-cell lung cancer: effects on survival and quality of life. J Clin Oncol 17: 3188-3194

Depierre A, Chastang C, Quoix E, Lebeau B, Blanchon F, Paillot N, Lemarie E, Milleron B, Moro D, Clavier J (1994) Vinorelbine versus vinorelbine plus cisplatin in advanced non-small cell lung cancer: a randomized trial. Ann Oncol 5: $37-42$

Depierre A, Milleron B, Moro-Sibilot D, Chevret S, Quoix E, Lebeau B, Braun D, Breton JL, Lemarie E, Gouva S, Paillot N, Brechot JM, Janicot H, Lebas FX, Terrioux P, Clavier J, Foucher P, Monchatre M, Coetmeur D, Level MC, Leclerc P, Blanchon F, Rodier JM, Thiberville L, Villeneuve A, Westeel V, Chastang C (2002) Preoperative Chemotherapy Followed by Surgery Compared With Primary Surgery in Resectable Stage I (Except T1N0), II, and IIIa Non-Small-Cell Lung Cancer. J Clin Oncol 20: 247-253

Deslauriers J, Gregoire J (2000) Surgical therapy of early non-small cell lung cancer. Chest 117: 104S-109S

Dillman RO, Seagren SL, Propert KJ, Guerra J, Eaton WL, Perry MC, Carey RW, Frei IIIEF, Green MR (1990) A randomized trial of induction chemotherapy plus high-dose radiation versus radiation alone in stage III non-small-cell lung cancer. $N$ Engl J Med 323: 940-945

Douillard J, Cosaert J, Barbarot V (2001a) Phase I trial of ZD0473 in combination with Vinorelbine for Patients with advanced cancer (abstract 274) Eur J Cancer 37(Suppl 6): S77

Douillard JY, Lerouge D, Monnier A, Bennouna J, Haller AM, Sun XS, Assouline D, Grau B, Riviere A (2001b) Combined paclitaxel and gemcitabine as first-line treatment in metastatic non-small cell lung cancer: a multicentre phase II study. Br J Cancer 84: 1179-1184

Dufour P, Bergerat JP, Eber M, Renaud P, Karcher V, Giron C, Leroy MJ, Oberling F (1990) Cisplatin-induced anemia: a potential interference with iron metabolism at erythroid progenitors level. Anticancer Drugs 1: 49-54 Eberhardt W, Wilke H, Stamatis G, Stuschke M, Harstrick A, Menker H, Krause B, Mueller MR, Stahl M, Flasshove M, Budach V, Greschuchna D, Konietzko N, Sack H, Seeber S (1998) Preoperative chemotherapy followed by concurrent chemoradiation therapy based on hyperfractionated accelerated radiotherapy and definitive surgery in locally advanced non-small-cell lung cancer: mature results of a phase II trial. J Clin Oncol 16: $622-634$ 
Einhorn LH, Loehrer PJ, Williams SD, Meyers S, Gabrys T, Nattan SR, Woodburn R, Drasga R, Songer J, Fisher W (1986) Random prospective study of vindesine versus vindesine plus high-dose cisplatin versus vindesine plus cisplatin plus mitomycin $\mathrm{C}$ in advanced non-small-cell lung cancer. J Clin Oncol 4: 1037-1043

Elliott JA, Ahmedzai S, Hole D, Dorward AJ, Stevenson RD, Kaye SB, Banham SW, Stack BH, Calman KC (1984) Vindesine and cisplatin combination chemotherapy compared with vindesine as a single agent in the management of non-small cell lung cancer: a randomized study. Eur J Cancer Clin Oncol 20: 1025-1032

Fauser AA, Fellhauer M, Hoffmann M, Link H, Schlimok G, Gralla RJ (1999) Guidelines for anti-emetic therapy: acute emesis. Eur J Cancer 35: $361-370$

Fields KK, Elfenbein GJ, Lazarus HM, Cooper BW, Perkins JB, Creger RJ, Ballester OF, Hiemenz JH, Janssen WE, Zorsky PE (1995) Maximum-tolerated doses of ifosfamide, carboplatin, and etoposide given over 6 days followed by autologous stem-cell rescue: toxicity profile. J Clin Oncol 13: $323-332$

Fink D, Howell S (eds) (2000) How does cisplatin kill cells. In PlatinumBased Drugs in Cancer Therapy, Kelland L, Farrell N (eds) pp 149-167 Totowa, NJ: Humana Press Inc

Fossella FV (1999a) Docetaxel in the treatment of non-small cell lung cancer: review of single-agent trials. Semin Oncol 26: 17-23; discussion 41-42

Fossella FV (1999b) Overview of docetaxel (Taxotere) in the treatment of non-small cell lung cancer. Semin Oncol 26: 4-8

Franciosi V, Barbieri R, Vasini G, Cacciani GC, Capra R, Cuomo A, Greco F, Bozzetti C, Cascinu S (2001) A feasible combination of gemcitabine and oxaliplatin (GEM-OXAL) in patients with advanced non-small cell lung cancer. Preliminary results of a phase II study. Proc Am Soc Clin Oncol 20: 263b (abstract 2804)

Furuse K, Fukuoka M, Kawahara M, Nishikawa H, Takada Y, Kudoh S, Katagami N, Ariyoshi Y (1999) Phase III study of concurrent versus sequential thoracic radiotherapy in combination with mitomycin, vindesine, and cisplatin in unresectable stage III non-small-cell lung cancer. J Clin Oncol 17: $2692-2699$

Gatzemeier U, Heckmayr M, Hossfeld DK, Zschaber R, Achterrath W, Lenaz L (1990a) Phase II study of carboplatin in untreated, inoperable nonsmall-cell lung cancer. Cancer Chemother Pharmacol 26: 369-372

Gatzemeier U, Heckmayr M, Neuhauss R, Hossfeld D, Achterrath W, Lenaz L (1990b) Phase II studies with carboplatin in non-small cell lung cancer. Semin Oncol 17: 25-31

Gatzemeier U, Rosell R, Betticher D, Keppler U, Macha HN, Pirker R, Berthet P, Brau JL, Bogaerts J, Gallant G (1999) Randomized Pan-European Trial comparing paclitaxel (TAX)/carboplatin (CAR) versus paclitaxel/cisplatin (CIS) in advanced non-small cell lung cancer (abstract). Eur J Cancer 35(Suppl 4): 973

Gatzemeier U, Twelves C, Anthoney DA, Pentheroudakis G, Groth G, Cosaert J (2001) A phase I dose-escalation study of ZD0473 combined with paclitaxel in refractory solid malignancies (abstract 264). Eur J Cancer 37(Suppl 6): S74

Gatzemeier U, von Pawel J, Gottfried M, ten Velde GP, Mattson K, DeMarinis F, Harper P, Salvati F, Robinet G, Lucenti A, Bogaerts J, Gallant G (2000) Phase III comparative study of high-dose cisplatin versus a combination of paclitaxel and cisplatin in patients with advanced non-small-cell lung cancer. J Clin Oncol 18: 3390 - 3399

Georgoulias V, Ardavanes A, Agelidon M, Papadakis E, Rapti A, Palamidas P, Toubis M, Kouroussis C, Polyzos A, Syrigos K (2002) Preliminary analysis of a multicenter phase III trial comparing docetaxel (D) versus docetaxel/ cisplatin (DC) in patients with inoperable advanced and metastatic nonsmall cell lung cancer (NSCLC) (abstract 1163). Proc Am Soc Clin Oncol 20: $291 \mathrm{a}$

Georgoulias V, Papadakis E, Alexopoulos A, Tsiafaki X, Rapti A, Veslemes M, Palamidas P, Vlachonikolis I (2001) Platinum-based and non-platinumbased chemotherapy in advanced non-small-cell lung cancer: a randomised multicentre trial. Lancet 357: 1478-1484

Giaccone G (2000) Clinical perspectives on platinum resistance. Drugs 59(Suppl 4): 9-17; discussion 37-38

Ginopoulos P, Spyropoulos K, Kardamakis D, Dougenis D, Onyenadum A, Gogos CH, Solomou E, Chrysanthopoulos K (1997) Advanced non-small cell lung cancer chemotherapy: a randomized trial of two active regimens (MVP and PE). Cancer Lett 119: $241-247$

Go RS, Adjei AA (1999) Review of the comparative pharmacology and clinical activity of cisplatin and carboplatin. J Clin Oncol 17: 409-422
Gralla RJ, Osoba D, Kris MG, Kirkbride P, Hesketh PJ, Chinnery LW, ClarkSnow R, Gill DP, Groshen S, Grunberg S, Koeller JM, Morrow GR, Perez EA, Silber JH, Pfister DG (1999) Recommendations for the use of antiemetics: evidence-based, clinical practice guidelines. American Society of Clinical Oncology. J Clin Oncol 17: 2971-2994

Grant SC, Kris MG (1995) New antineoplastic agents in lung cancer 19881993. Cancer Treat Res 72: $323-347$

Hamilton CR, Bliss JM, Horwich A (1989) The late effects of cis-platinum on renal function. Eur J Cancer Clin Oncol 25: 185-189

Hoctin-Boes G, Cosaert J, Koehler M, Smith M (2001) Safety profile of ZD0473 in phase II trials of patients with advanced cancers (poster). $\mathrm{Br}$ Cancer Res Meeting July 2001

Hoffman PC, Mauer AM, Otterson GA, Rudin CM, Villalona MA, Golomb HM, Wade JL, Lanzanotti VJ, Ansari RH, Szeto LL, Vokes EE (2001) Phase II study of oxaliplatin and paclitaxel in advanced non-small cell lung cancer (NSCLC) (abstract). Proc Am Soc Clin Oncol 20: A2852, p. 275b

Holford J, Raynaud F, Murrer BA, Grimaldi K, Hartley JA, Abrams M, Kelland LR (1998a) Chemical, biochemical and pharmacological activity of the novel sterically hindered platinum co-ordination complex, cis[amminedichloro(2-methylpyridine)] platinum(II) (AMD473). Anticancer Drug Des 13: $1-18$

Holford J, Sharp SY, Murrer BA, Abrams M, Kelland LR (1998b) In vitro circumvention of cisplatin resistance by the novel sterically hindered platinum complex AMD473. Br J Cancer 77: 366-373

Huisman C, Smit EF, Giaccone G, Postmus PE (2000) Second-line chemotherapy in relapsing or refractory non-small-cell lung cancer: a review. J Clin Oncol 18: 3722 - 3730

Jeremic B, Shibamoto Y, Milicic B, Milisavljevic S, Nikolic N, Dagovic A, Aleksandrovic J, Radosavljevic-Asic G (1999) A phase II study of concurrent accelerated hyperfractionated radiotherapy and carboplatin/oral etoposide for elderly patients with stage III non-small-cell lung cancer. Int J Radiat Oncol Biol Phys 44: 343-348

Johnson DH (1995) Phase III trial (E5592) comparing cisplatin plus etoposide with cisplatin plus paclitaxel at two dose levels for treatment of advanced non-small-cell lung cancer. Eastern Cooperative Oncology Group. J Natl Cancer Inst Monogr 19: 61-63

Johnson DH (2000) Evolution of cisplatin-based chemotherapy in non-small cell lung cancer: a historical perspective and the eastern cooperative oncology group experience. Chest 117(Suppl): S133-S137

Judson I, Cerny T, Epelbaum R, Dunlop D, Smyth J, Schaefer B, Roelvink M, Kaplan S, Hanauske A (1997) Phase II trial of the oral platinum complex JM216 in non-small-cell lung cancer: an EORTC early clinical studies group investigation. Ann Oncol 8: 604-606

Judson I, Kelland LR (2000) New developments and approaches in the platinum arena. Drugs 59(Suppl 4): 29-36; discussion 37-38

Kawahara M, Furuse K, Kodama N, Yamamoto M, Kubota K, Takada M, Negoro S, Kusunoki Y, Matui K, Takifuji N (1991) A randomized study of cisplatin versus cisplatin plus vindesine for non-small cell lung carcinoma. Cancer 68: 714-719

Kelland LR (2000) Preclinical perspectives on platinum resistance. Drugs 59:(Suppl 4): 1-8; discussion 37-38

Kelly K, Crowley J, Bunn PA, Presant CA, Grevstad PK, Moinpour CM, Ramsey SD, Wozniak AJ, Weiss GR, Moore DF, Israel VK, Livingston RB, Gandara DR (2001) Randomized phase III trial of paclitaxel plus carboplatin versus vinorelbine plus cisplatin in the treatment of patients with advanced non-small-cell lung cancer: a Southwest Oncology Group trial. J Clin Oncol 19: 3210-3218

Klastersky J, Sculier JP, Bureau G, Libert P, Ravez P, Vandermoten G, Thiriaux J, Lecomte J, Cordier R, Dabouis G (1989) Cisplatin versus cisplatin plus etoposide in the treatment of advanced non-small-cell lung cancer. Lung Cancer Working Party, Belgium. J Clin Oncol 7: 1087-1092

Klastersky J, Sculier JP, Lacroix H, Dabouis G, Bureau G, Libert P, Richez M, Ravez P, Vandermoten G, Thiriaux J (1990) A randomized study comparing cisplatin or carboplatin with etoposide in patients with advanced nonsmall-cell lung cancer: European Organization for Research and Treatment of Cancer Protocol 07861. J Clin Oncol 8: 1556-1562

Kreisman H, Goutsou M, Modeas C, Graziano SL, Costanza ME, Green MR (1990) Cisplatin-carboplatin therapy in extensive non-small cell lung cancer: a Cancer and Leukemia Group B study. Eur J Cancer 26: 10571060 
Le Chevalier T, Arriagada R, Quoix E, Ruffie P, Martin M, Tarayre M, Lacombe-Terrier MJ, Douillard JY, Laplanche A (1991) Radiotherapy alone versus combined chemotherapy and radiotherapy in nonresectable non-small-cell lung cancer: first analysis of a randomized trial in 353 patients. J Natl Cancer Inst 83: 417-423

Le Chevalier T, Brisgand D, Douillard JY, Pujol JL, Alberola V, Monnier A, Riviere A, Lianes P, Chomy P, Cigolari S (1994) Randomized study of vinorelbine and cisplatin versus vindesine and cisplatin versus vinorelbine alone in advanced non-small-cell lung cancer: results of a European multicenter trial including 612 patients. J Clin Oncol 12: 360-367

Lilenbaum RC, Herndon J, List M, Desch C, Watson D, Holland J, Weeks JC Green MR (2002) Single-agent (SA) versus combination chemotherapy (CC) in advanced non-small cell lung cancer (NSCLC): a CALGB randomised trial of efficacy, quality of life (QOL) and cost-effectiveness (abstract 2). Proc Am Soc Clin Oncol 20: 1a

Lilenbaum RC, Langenberg P, Dickersin K (1998) Single agent versus combination chemotherapy in patients with advanced nonsmall cell lung carcinoma: a meta-analysis of response, toxicity, and survival. Cancer $\mathbf{8 2}$ $116-126$

Lokich J, Anderson N (1998) Carboplatin versus cisplatin in solid tumors: an analysis of the literature. Ann Oncol 9: 13-21

Marino P, Preatoni A, Cantoni A, Buccheri G (1995) Single-agent chemotherapy versus combination chemotherapy in advanced non-smal cell lung cancer: a quality and meta-analysis study. Lung Cancer 13: 1-12

McKeage MJ (1995) Comparative adverse effect profiles of platinum drugs. Drug Saf 13: $228-244$

Miller VA, Kris MG (2000) Docetaxel (Taxotere) as a single agent and in combination chemotherapy for the treatment of patients with advanced non-small cell lung cancer. Semin Oncol 27: 3-10

Monnet I, Brienza S, Hugret F, Voisin S, Gastiaburu J, Saltiel JC, Soulie P, Armand JP, Cvitkovic E, de Cremoux H (1998) Phase II study of oxaliplatin in poor-prognosis non-small cell lung cancer (NSCLC). ATTIT. Association pour le Traitement des Tumeurs Intra Thoraciques. Eur J Cancer 34: 1124-1127

Monnet I, de Cremoux H, Soulié P, Saltiel-Voisin S, Bekkrada M, Saltiel JC, Brain E, Rixe O, Yataghene Y, Misset JL, Cvitkovic E (2002) Oxaliplatin plus vinorelbine in advanced-non-small-cell lung cancer: final results of a multicenter phase II study. Ann Oncol 13: 103-107

Mountain CF (1997) Revisions in the International System for Staging Lung Cancer. Chest 111: $1710-1717$

Natale RB (1998) Experience with new chemotherapeutic agents in non-small cell lung cancer. Chest 113(Suppl): S32-S39

Non-Small Cell Lung Cancer Collaborative Group (1995) Chemotherapy in non-small cell lung cancer: a meta-analysis using updated data on individual patients from 52 randomised clinical trials. Non-small Cell Lung Cancer Collaborative Group. BMJ 311: 899-909

O'Dwyer PJ, Stevenson JP, Redlinger M, Sun W, Giantonio B, Hahn S, Algazy K, Burnite M, Koehler M (2001) Phase I Trial of the Novel Platinum Analogue ZD0473 in Combination with Gemcitabine (GEM) for Patients with Advanced Cancers (abstract). Proc Am Soc Clin Oncol 20: A1354, p. 339a

Pisters KM, Ginsberg RJ, Giroux DJ, Putnam Jr JB, Kris MG, Johnson DH, Roberts JR, Mault J, Crowley JJ, Bunn Jr PA (2000) Induction chemotherapy before surgery for early-stage lung cancer: A novel approach. Bimodality Lung Oncology Team. J Thorac Cardiovasc Sur 119: 429-439

Ranson M, Davidson N, Nicolson M, Falk S, Carmichael J, Lopez P, Anderson H, Gustafson N, Jeynes A, Gallant G, Washington T, Thatcher N (2000) Randomized trial of paclitaxel plus supportive care versus supportive care for patients with advanced non-small-cell lung cancer. $J$ Natl Cancer Inst 92: $1074-1080$

Raynaud FI, Boxall FE, Goddard PM, Valenti M, Jones M, Murrer BA, Abrams M, Kelland LR (1997) cis-Amminedichloro(2-methylpyridine) platinum(II) (AMD473), a novel sterically hindered platinum complex: in vivo activity, toxicology, and pharmacokinetics in mice. Clin Cancer Res 3: 2063-2074

Rodriguez J, Pawel J, Pluzanska A, Gorbounova V, Fossella F, Kaukel E, Mattson K, Millward M, Kim YS, Gamza F, Berilie J, Belani CP (2001) A multicenter, randomised phase III study of docetaxel + cisplatin (DC) and docetaxel + carboplatin (DCB) vs. vinorelbine + cisplatin (VC) in chemotherapy-naive patients with advanced and metastatic non-small cell lung cancer (abstract 1252). Proc Am Soc Clin Oncol 20: 314a

Rosell R, Felip E (2001) Predicting response to paclitaxel/carboplatin-based therapy in non-small cell lung cancer. Semin Oncol 28(Suppl 14): S37-S44
Rosell R, Gomez-Codina J, Camps C, Maestre J, Padille J, Canto A, Mate JL, Li S, Roig J, Olazabal A (1994) A randomized trial comparing preoperative chemotherapy plus surgery with surgery alone in patients with non-smallcell lung cancer. N Engl J Med 330: 153-158

Rosso R, Salvati F, Ardizzoni A, Gallo Curcio C, Rubagotti A, Belli M, Castagneto B, Fusco V, Sassi M, Ferrara G (1990) Etoposide versus etoposide plus high-dose cisplatin in the management of advanced non-small cell lung cancer. Results of a prospective randomized FONICAP trial. Italian Lung Cancer Task Force. Cancer 66: $130-134$

Roszkowski K, Pluzanska A, Krzakowski M, Smith AP, Saigi E, Aasebo U, Parisi A, Pham Tran N, Olivares R, Berille J (2000) A multicenter, randomized, phase III study of docetaxel plus best supportive care versus best supportive care in chemotherapy-naive patients with metastatic or nonresectable localized non-small cell lung cancer (NSCLC). Lung Cancer 27: $145-157$

Roth JA, Atkinson EN, Fossella F, Komaki R, Bernadette Ryan M, Putnam Jr JB, Lee JS, Dhingra H, De Caro L, Chasen M, Hong WK (1998) Long-term follow-up of patients enrolled in a randomized trial comparing perioperative chemotherapy and surgery with surgery alone in resectable stage IIIA non-small-cell lung cancer. Lung Cancer 21: 1-6

Roth JA, Fossella F, Komaki R, Ryan MB, Putnam Jr JB, Lee JS, Dhingra H, De Caro L, Chasen M, McGavran M (1994) A randomized trial comparing perioperative chemotherapy and surgery with surgery alone in resectable stage IIIA non-small-cell lung cancer. J Natl Cancer Inst 86: 673-680

Rowell NP, Williams CJ (2001) Radical radiotherapy for stage I/II non-small cell lung cancer in patients not sufficiently fit for or declining surgery (medically inoperable) (Cochrane Review). In The Cochrane Library, 1, 2001. Oxford: Update Software

Ruckdeschel JC, Finkelstein DM, Mason BA, Creech RH (1985) Chemotherapy for metastatic non-small-cell bronchogenic carcinoma: EST 2575, generation $\mathrm{V}-\mathrm{a}$ randomized comparison of four cisplatin-containing regimens. J Clin Oncol 3: 72-79

Sandler AB, Nemunaitis J, Denham C, von Pawel J, Cormier Y, Gatzemeier U, Mattson K, Manegold C, Palmer MC, Gregor A, Nguyen B, Niyikiza C, Einhorn LH (2000) Phase III trial of gemcitabine plus cisplatin versus cisplatin alone in patients with locally advanced or metastatic non-smallcell lung cancer. J Clin Oncol 18: 122-130

Scagliotti GV, De Marinis F, Rinaldi M, Crino L, Gridelli C, Ricci S, Bianco A Boni C, Marangolo M, Failla G, Adamo V, Altavilla G, Ceribelli A, Clerici $\mathrm{M}$, Di Costanzo F, Frontini L, Tonato $\mathrm{M}$ on behalf of the Italian Lung Cancer Project (2001) Phase III randomised trial comparing three platinum-based doublets in advanced non-small cell lung cancer (abstract 1227). Proc Am Soc Clin Oncol 20: 308a

Schaake-Koning C, van den Bogaert W, Dalesio O, Festen J, Hoogenhout J, van Houtte P, Kirkpatrick A, Koolen M, Maat B, Nijs A (1994) Radiosensitization by cytotoxic drugs. The EORTC experience by the Radiotherapy and Lung Cancer Cooperative Groups. Lung Cancer 10(Suppl 1): S263S270

Schiller JH, Harrington D, Belani CP, Langer C, Sandler A, Krook J, Zhu J, Johnson DH (2002) Comparison of four chemotherapy regimens for advanced non-small-cell lung cancer. $N$ Engl J Med 346: 92-98

Sederholm C (2002) Gemcitabine (G) compared with gemcitabine plus carboplatin (GC) in advanced non-small cell lung cancer (NSCLC): a phase III study by the Swedish Lung Cancer Study Group (SLUSG). Proc Am Soc Clin Oncol 20: 291a (abstract 1162)

Sessa C, Capri G, Gianni L, Peccatori F, Grasselli G, Bauer J, Zucchetti M, Vigano L, Gatti A, Minoia C, Liati P, Van den Bosch S, Bernareggi A, Camboni G, Marsoni S (2000) Clinical and pharmacological phase I study with accelerated titration design of a daily times five schedule of BBR3464, a novel cationic triplatinum complex. Ann Oncol 11: 977-983

Shepherd FA, Dancey J, Ramlau R, Mattson K, Gralla R, O’Rourke M, Levitan N, Gressot L, Vincent M, Burkes R, Coughlin S, Kim Y, Berille J (2000) Prospective randomized trial of docetaxel versus best supportive care in patients with non-small-cell lung cancer previously treated with platinum-based chemotherapy. J Clin Oncol 18: 2095-2103

Socinski MA, Langer CJ (1999) Single-agent paclitaxel and paclitaxel/nonplatinum combination therapy in advanced non-small cell lung cancer. Semin Oncol 26: 51-61; discussion 71-72

Soria JC, Brisgand D, Le Chevalier T (2001) Do all patients with advanced non-small-cell lung cancer benefit from cisplatin-based combination therapy? Ann Oncol 12: $1667-1670$ 
Souquet JP, Tan EH, Pereira JR, Klaveren RV (2001) GLOB1, A prospective randomised phase III trial comparing Vinorelbine and Cisplatin (NP) versus Vinorelbine, ifosfamide and cisplatin (NIP) in metastatic NSCLC patients (PTS): A Patient's benefit analysis. Proc Am Soc Clin. Oncol 20: A1337 (abstract)

Splinter TA (1990) Chemotherapy in advanced non-small cell lung cancer. Eur J Cancer 26: $1093-1099$

Splinter TA, Sahmoud T, Festen J, van Zandwijk N, Sorenson S, Clerico M, Burghouts J, Dautzenberg B, Kho GS, Kirkpatrick A, Giaccone G (1996) Two schedules of teniposide with or without cisplatin in advanced nonsmall-cell lung cancer: a randomized study of the European Organization for Research and Treatment of Cancer Lung Cancer Cooperative Group. J Clin Oncol 14: 127-134

Stephens RJ, Fairlamb D, Gower N, Maslove L, Milroy R, Napp V, Peake MD, Rudd RM, Spiro S, Thorpe H, Waller D (2002) The Big Lung Trial (BLT): determining the value of cisplatin-based chemotherapy for all patients with non-small cell lung cancer (NSCLC). Preliminary results in the supportive care setting (abstract 1161). Proc Am Soc Clin Oncol 20: 291a

Trigo JM, Beale P, Judson IR, Raynaud F, Rees C, Milan D, Wolf L, Walker R, Hanwell J, Giandomenico C (1999) Phase I and Pharmacokinetic (PK) Study of Cis-Amminedichloro (2-Methylpyridine) Platinum (II) (ZD0473), a Novel Sterically Hindered Platinum Complex, in Patients (pts) with Advanced Solid Malignancies. Proc Am Soc Clin Oncol 18: A648 (abstract)

Trovo MG, Minatel E, Franchin G, Boccieri MG, Nascimben O, Bolzicco G, Pizzi G, Torretta A, Veronesi A, Gobitti C (1992) Radiotherapy versus radiotherapy enhanced by cisplatin in stage III non-small cell lung cancer. Int J Radiat Oncol Biol Phys 24: $11-15$
Van Meerbeeck JP, Smit EF, Lianes P, Schramel F, Lenz M, Debruyne C, Giaccone G (EORTC Lung Cancer Groupe) (2001) A EORTC randomised phase III trial of three chemotherapy regimens in advanced non-small cell lung cancer (NSCLC). Proc Am Soc Clin Oncol 20: 308a (abstract 1228)

von Pawel J, von Roemeling R, Gatzemeier U, Boyer M, Elisson LO, Clark P, Talbot D, Rey A, Butler TW, Hirsh V, Olver I, Bergman B, Ayoub J, Richardson G, Dunlop D, Arcenas A, Vescio R, Viallet J, Treat J (2000) Tirapazamine plus cisplatin versus cisplatin in advanced non-small-cell lung cancer: A report of the international CATAPULT I study group. Cisplatin and Tirapazamine in Subjects with Advanced Previously Untreated Non-Small-Cell Lung Tumors. J Clin Oncol 18: 1351 - 1359

Wood PA, Hrushesky WJ (1995) Cisplatin-associated anemia: an erythropoietin deficiency syndrome. J Clin Invest 95: 1650-1659

Wozniak AJ, Crowley JJ, Balcerzak SP, Weiss GR, Spiridonidis CH, Baker LH, Albain KS, Kelly K, Taylor SA, Gandara DR, Livingston RB (1998) Randomized trial comparing cisplatin with cisplatin plus vinorelbine in the treatment of advanced non-small-cell lung cancer: a Southwest Oncology Group study. J Clin Oncol 16: 2459-2465

Zatloukal P, Petruzelka L, Zemanova M, Kolek V, Grygarkova I, Sixtova D, Roubec J, Horenkova E, Kuta M, Havel L, Prusa P, Novakova L Czech Lung Cancer Cooperative Group (2001) Gemcitabine plus cisplatin (GCis) versus gemcitabine plus carboplatin (GCarb) in patients (Pts) with nonsmall cell lung cancer (NSCLC) stage IIIb and IV: and interim analysis of a randomized trial. Proc Am Soc Clin Oncol 20: A1343 (abstract), p. 337a 